\title{
THE NATIONAL EXECUTIVE COMMITTEE, MAY TO SEPTEMBER 1979
}

Four meetings of this committee have been held since the Council Meeting of April this year. Matters discussed at each meeting include items carried over from previous meetings the implementation of resolutions passed at Council, finance, reports of sub-committees, reports of special groups, branch matters and anything concerning W.C.P.T.

\section{ITEMS CARRIED OVER FROM THE PREVIOUS N.E.C.}

The possibility of getting the Tertiary Education Diploma (Unisa) accepted as a registrable additional qualification seems a little nearer following a meeting between the Dean of the Faculty of Education at Unisa, Mrs. Mathias, Misses Bowerbank and Irwin-Carruthers. Unisa is giving as much co-operation as they can in this connection.

The list of approved employing authorities for registered physiotherapists (i.e. authorities other than registered physiotherapist or specialists in physical medicine) has been revised at the request of the Professional Board. This now reads: Department of Health, Department of National Education, Departments of Coloured and Indian Affairs, Department of Education and Training (Bantu Education), Departments of Defence, Provincial Administrations, Municipalities, Benefit Societies, Universities (provided that the employment is in a teaching or research capacity), National Council for the Care of Cripples and its affiliated bodies, and any other body subject to the approval of National Council, e.g. Hospitals and Establishments of the Mining and other Industries, Geriatric Institutions, Institutions for the Mentally and/or Physically Handicapped. Physiotherapists offered employment by any other body should contact the National Executive Committee.

Negotiations are still proceeding in order to legalise the administration of certain drugs by physiotherapists.

Mrs. Jaholkowski's very comprehensive report on industrial physiotherapy was discussed by both the National Executive Committee and the National Committee of Representatives and plans are under way for Mrs. Jaholkowski to visit the branches.
The latest invasion of the scope of physiotherapy is the Critical Care Society's proposals for the establishment of a new profession in this country - respiratory technicians. This does not appear, at this stage, to have support from any authority outside the Critical Care Society, but the N.E.C., as well as writing to the Critical Care Society, has made further representations through our Honorary Vice-Presidents and through the S.A. Society of Anaesthetists.

The Chiropractors' Association have submitted a letter purporting to counter our objections to the Chiropractors' Act. However, their letter in no way counters the many ambiguous points raised in the S.A.S.P's memorandum, particularly relating to the scope of chiropractic and to the very minimal penalties for misconduct. The Medical Association is in agreement with our objections and has written to the Department of Health, opposing the Chiropractors' Act.

\section{IMPLEMENTATION OF RESOLUTIONS PASSED AT COUNCIL}

In order to involve our Honorary Vice-Presidents more in the affairs of the Society it was agreed to enlist their support regarding the Chiropractors' Act and the proposed establishment of respiratory technicians.

Action has been taken on all resolutions passed at Council but few matters have been finalised yet as we await replies from various bodies. The two matters which interest most members are the question of tax-deductible interest most members are the question of the possibility of registering an epaulette. Due to the recent report of the Franzen Commission there is, unfortunately, no possibility of getting the provisions of Section 16 of the Income Tax Act extended to include phvsiotherapists.

The State Herald has indicated that there is no objection to the registration of an epaulette providing that the design does not include lettering. The Society's the lettering, and the Hospital Group have been asked for a decision on the colour of the epaulette.

As a result of suggestions received from the Branches the Society plans to arrange abridged courses on prac- 
tical neurodevelopmental therapy and on mobilisation techniques (Maitland) on a regional basis.

Regarding post-basic courses run by the Society, it has been suggested that Branches who run post-basic courses should pay a percentage of the profits to the P.P.K. Fund. In return, Branches may retain a percentage of the profits of any N.E.C.-organised course held in their area. In respect of Branch boundaries a new map showing these has been sent to each Branch Secretary.

\section{FINANCE}

The total paid-up membership is 1134 excluding student members. A separate Finance Committee is handling much of the financial business of the Society, making its recommendations to the N.E.C. Now that it has been agreed that application may be made to the P.P.K. Fund for loans or grants it was necessary to set up an application form, which has been done. The interest available on investments is at present $R 700,00$ $\mathrm{p} . \mathrm{a}$. This will increase when money from the special savings account is invested in the near future, but is not enough to cover repetition of the R1 000 given as outright grants in 1979. The Finance Committee feel that where possible, loans rather than grants should be awarded. The loan would be interest-free and they suggest that instead of the individual being responsible for repayment of the loan as such, he/she should be asked to run courses or lectures, part of the profits being used for repayment of the loan.

\section{REPORTS OF SUB-COMMITTEES}

There are, apart from the Finance Committee, six standing Sub-Committees of N.E.C. - the Activations Committee, the Afrikaans Translation Committee, the Constitutional Sub-Committee, The Editorial Board, the Registration Committee and the newly-formed Investigating Committee for salaries, conditions of service and registration of post-graduate courses.

The Constitutional Sub-Committee met in September to study the amendments to the Constitution and ByeLaws as passed at Council and work has been started on incorporating them in the Constitution.

The only other matters of immediate interest to members were contained in the report of the Investigation Committee.

\section{SALARIES AND CONDITIONS OF SERVICE}

It was agreed to ask the teaching and other large hospitals, where the staff situation was most acute, to submit their total number of posts and posts occupied at this time so that N.E.C. could write a letter to the Department of Health proving the shortage and pressing for higher salaries. It was also agreed to investigate the restructuring of post-allocation (based upon type of work as well as number of beds) and submit recommendations which could be forwarded through the correct channels.

Information had been requested and received on conditions of service under various employing authorities; this is being correlated prior to making any recommendations on improved conditions of service.

\section{REGISTRATION OF POST-GRADUATE COURSES}

It was agreed to submit the syllabus for a proposed extended course in neurodevelopmental therapy to the Professional Board (and the S.A.M.D.C.) as a test-case, asking the Professional Board to appoint examiners and the S.A.M.D.C. to act as the examining body.

It was agreed that the merit award system of the Department of National Education and the Transvaal Provincial Administration had many disadvantages and many employing authorities, such as the Cape Provincial Administration, do not have merit award systems. It was agreed to investigate the possibility of an accreditatio system as already operating overseas; once recommer. dations have been formulated an approach will be made to the Public Service Commission. So far the Public Service Commission only recognises South African registrable physiotherapy education qualifications and any masters or doctors degrees.

\section{SPECIAL GROUPS/ASSOCIATIONS}

There are five Special Groups/Association of the Society. - the Lecturers' Group, the Manipulative Therapists' Group, the National Hospital Group, the Obstetric Association and the Private Practitioners' Association.

The N.E.C. agreed with a suggestion by the Lecturers' Group that an annotation on ethical principles in research should be published in the Journal and that the Private Practitioners' Association should be asked to suggest to its members that, for their own protection, they submit details of any research projects which they may be undertaking to the N.E.C.

\section{W.C.P.T.}

Due to the delay in publication of the W.C.P.T. 8th Congress Proceedings permission has been given to authors of papers to publish elsewhere provided acknowledgement is made that the paper was originally presented at the Congress.

The first regional seminar of the W.C.P.T. will b held in Geneva from $1-4$ October 1980. Details an available from the Office Secretary.

\section{S. H. Irwin-Carruthers}

